\title{
Insights into Novel Prognostic and Possible Predictive Biomarkers of Lung Neuroendocrine Tumors
}

\author{
DIMITRIOS MORIS ${ }^{1}$, IOANNIS NTANASIS-STATHOPOULOS ${ }^{2}$, DIAMANTIS I. TSILIMIGRAS ${ }^{3}$, \\ MOHAMAD A. ADAM ${ }^{1}$, CHIFU JEFFREY YANG ${ }^{1}$, DAVID HARPOLE ${ }^{1}$ and STAMATIOS THEOCHARIS ${ }^{3}$ \\ ${ }^{1}$ Department of Surgery, Duke University, Durham, NC, U.S.A.; \\ ${ }^{2}$ Department of Clinical Therapeutics, Alexandra General Hospital, and \\ ${ }^{3}$ First Department of Pathology, National and Kapodistrian University of Athens, Athens, Greece
}

\begin{abstract}
Primary lung neuroendocrine tumors (NETs) consist of typical and atypical carcinoids, large-cell neuroendocrine carcinomas and small-cell lung carcinomas. NETs are highly heterogeneous in histological characteristics, clinical presentation and natural history. While there are morphological and immunohistochemical criteria to establish diagnosis, there is a lack of universal consensus for prognostic factors or therapeutic targets for personalized treatment of the disease. Thus, identifying potential markers of neuroendocrine differentiation and prognostic factors remains of high importance. This review provides an insight into promising molecules and genes that are implicated in NET carcinogenesis, cell-cycle regulation, chromatin remodeling, apoptosis, intracellular cascades and cell-cell interactions. Additionally it supports a basis for classifying these tumors into categories that distinct molecular characteristics and disease natural history, which may have a direct impact on treatment options. In light of the recent approval of everolimus, mammalian target of rapamycin pathway inhibition and related biomarkers may play a central role in the treatment of pulmonary NETs. Future clinical trials that integrate molecular profiling are deemed necessary in order to treat patients with NET on a personalized basis.
\end{abstract}

Lung cancer remains one of the most frequent and lethal types of cancer worldwide. The recent World Health Organization

This article is freely accessible online.

Correspondence to: Dimitrios Moris, MD, Ph.D., Department of Surgery, Duke University, Durham, NC 27705, U.S.A. E-mail: dimmoris@yahoo.com

Key Words: NET, biomarkers, prognosis, lung neoplasms, review.
(WHO) classification distinguishes five major types of lung cancer: adenocarcinoma, squamous-cell carcinoma, small-cell lung carcinoma (SCLC), large-cell neuroendocrine carcinoma (LCNEC), and carcinoid tumors (1). Although the development of next-generation sequencing techniques has afforded comprehensive opportunities to study lung tumors and the emergence of novel therapeutics, very little has been translated into improving patient survival. Over the past 20 years, the average 5-year overall survival rate for lung cancer has remained stable at around $15 \%$ (2).

Primary lung neuroendocrine tumors (NETs) are highly heterogeneous in histological characteristics, clinical presentation and disease course. The histological variants of NETs, including typical carcinoid, atypical carcinoid, LCNEC and SCLC (3). Typical and atypical carcinoid are well-differentiated but differ in cellular atypia and mitotic yield; overall, these carcinoids have a more favorable prognosis compared to LCNEC and SCLC, which account for $15-20 \%$ of lung cancer-related deaths (2).

Genetic and molecular profiling of resected tumors have revealed potential targets for personalized anticancer therapeutics and pinpoint towards an emerging molecular taxonomy of cancer, in general $(4,5)$ and in lung neoplasia (6). Substantial research efforts are being made in order to determine molecular signatures that may have prognostic value and may constitute therapeutic targets (7). Thus, the aim of this review was to summarize and critically evaluate the emerging data on prognostic and possible predictive biomarkers in lung NETs.

\section{Mammalian Target of Rapamycin Pathway}

The mammalian target of rapamycin (mTOR) pathway plays a key role in cellular processes by regulating protein synthesis, cell growth and metabolic systems. Deregulation 
of the mTOR signaling pathway is implicated in several tumor types, including NETs, raising the potential for being an attractive target for therapy (8-10). High frequencies of gene copy-number alterations in genes encoding members of the PI3K-AKT-mTOR pathway were detected in SCLC (11). In an immunohistochemical study of AKT and mTOR expression in bronchopulmonary NETs, phosphorylated AKT and mTOR were found in the majority of cases, suggesting a central role for this pathway in NET carcinogenesis (12). It should be noted that higher expression of these molecules was shown in carcinoids compared to LCNECs and SCLCs. Interestingly, mTOR expression was inversely associated with greater tumor stage in LCNECs and SCLCs, with T1T2 tumors having higher levels of phosphorylated mTOR than T3-T4 ones (12). The similarity in genomic profiling between LCNEC and SCLC was addressed in a recent study using capture sequencing of all the coding exons of 244 cancer-related genes (13). These results highlight that highgrade and more aggressive NETs may have molecular hallmarks distinct from those of low- and intermediate-grade tumors, which could have diagnostic and therapeutic clinical implications (12).

Preclinical data suggest that targeting mTOR pathway in pulmonary NETs is a feasible therapeutic strategy. Rapamycin has been shown to reduce carcinoid proliferation both in vitro (BON-1, H727 and MTC cell lines) and in BON-1 xenograft models $(14,15)$. Moreover, everolimus has been shown to reduce secretion of vascular endothelial growth factor and cell viability in human primary bronchial carcinoid cell cultures (16).

The RAD001 in Advanced Neuroendocrine Tumors, Fourth Trial (RADIANT-4) has increased the interest in the mTOR pathway in NETs $(17,18)$. This phase III, randomized clinical trial included 302 patients with advanced, progressive, non-functional, pulmonary or gastrointestinal NETs that received either the mTOR inhibitor everolimus (10 $\mathrm{mg} /$ day $)$, or placebo, with supportive care optimized for the two groups. Patients treated with everolimus benefited with prolonged progression-free survival and had a $52 \%$ reduction in the estimated risk of progression or death (hazard ratio $=0.48$, $95 \%$ confidence interval $=0.35-0.67, p<0.00001)$ (17). These results led to the expansion of Food and Drug Administration approval for everolimus to progressive, well-differentiated, nonfunctional NETs of lung or gastrointestinal origin that are unresectable, locally advanced, or metastatic (19). Currently, combinations of everolimus with other agents are being investigated in phase I and phase II clinical trials (18).

Potential markers predicting sensitivity to mTOR inhibitors have been also suggested, such as total mTOR level, AKT, p70S6K (RPS6KB2), and mitogen-activated protein/extracellular signal-regulated kinases (MAPK/ERK) levels in patients with pulmonary carcinoids (20). In SCLC cells, high expression of eukaryotic translation initiation factor $4 \mathrm{E}(\mathrm{elF} 4 \mathrm{E})$ was associated with increased resistance to everolimus treatment. The mTOR-independent activation of elF4E pathway mediated by MYC has been suggested as a mechanism contributing to everolimus resistance and has provided the rationale for its inhibition in future studies (21).

\section{Cell-cycle Regulatory Genes}

The expression of tumor protein 53 (TP53) and retinoblastoma protein $1(R B 1)$ cell-cycle checkpoint genes in lung NETs has been assessed by whole-exome and targeted sequencing, with a significantly higher mutational load detected in carcinomas (70.0\%) compared with carcinoids (10.2\%) (22). Loss of RB1 was frequently encountered in all lung NET subtypes, mainly in SCLC (69.7\%) and LCNEC (55.6\%) compared to typical (24.5\%) and atypical carcinoids (11.4\%). Regarding SCLC in particular, homozygous deletions comprised $39.4 \%$ of the cases. Moreover, when loss of heterozygosity was also included, the $R B 1$ alterations prevailed among SCLC cases, at $91 \%$ (22). Loss of TP53 was also frequent among highgrade NETs, as it was detected in $48.5 \%$ of SCLC and $40.7 \%$ of LCNEC cases, whereas fewer than one-third of carcinoids presented with TP53 losses. Conversely, loss of heterozygosity of multiple endocrine neoplasia type 1 (MEN1) was more frequently detected in carcinoids $(15.1 \%$ in typical and $22.9 \%$ in atypical) compared to LCNEC $(3.7 \%)$ and SCLC (0\%) (22). Thus, it has been suggested that TP53 and RB1 transcription patterns may help distinguish between SCLC- and NSCLC-like LCNECs (23).

Walter et al. reported results of a comparative mRNA expression analysis among lung NETs subtypes (24). By investigating a panel of mRNAs implicated in cell-cycle regulation (such as cyclin-dependent kinases (CDKs)] and apoptosis, they found a lower expression of Achaete-scute homolog 1 (ASCL1), B-cell lymphoma 2 (BCL2), caspase 8 (CASP8), $\mathrm{G}_{1} / \mathrm{S}$-specific cyclin-E1 (CCNE1), CDK1, CDK2, $C D K N 1 A$ and $C D K N 2 A$ in carcinoids compared to carcinomas. An inverse association was found for CCNE1 and CDK6 (24). These findings provide evidence that carcinoids and carcinomas control $R B 1$ expression in different ways, by modulating a different subset of cell-cycle regulators. In the analysis, SCLC had a profile discernible from that of LCNEC, by having a higher expression of $C D K 2, C D K N 1 B, C D K N 2 A$ and $P N N$ genes compared to the latter (24). Interestingly, minimal $C C N D 1$ and $C D K N 2 A$ expression was correlated with N0 status, whereas low BCL2 expression was associated with absence of venous invasion. It should be noted that Walter et al. also identified $\beta$-actin (ACTB), CDKNIB, glyceraldehyde 3-phosphate dehydrogenase $(G A P D H)$, growth factor receptor-bound protein 2 (GRB2), Ras homolog gene family, member A 
(RHOA) and syndecan-binding protein $(S D C B P)$ as reference genes in NETs, due to their stable and reliable expression in mRNA expression analysis (25).

To date, various gene abnormalities have been reported to occur frequently in SCLC and LCNEC but are rarely observed in typical carcioids (26). All carcinoid tumors were characterized by diffuse RB1 expression, which was absent from SCLCs and LCNECs. On the contrary, all SCLCs and LCNECs demonstrated intense and diffuse P53 expression (27), in contrast to carcinoids (28). Endo et al. evaluated the expression patterns of developing neural cell-specific transcription factors (DNTFs) (including BRN2, thyroid transcription factor 1 (TTF1) and ASCL1)] in patients with resectable lung NETs (27). SCLCs and LCNECs unanimously expressed DNTFs, which were also expressed in a subset of carcinoids (27). DNTs have also been detected in the setting of diffuse idiopathic pulmonary neuroendocrine cell hyperplasia, which is a debatable entity regarding its premalignant potential (29). LCNECs and SCLCs have also demonstrated a higher expression of nuclear survivin, which is essential for the completion of mitosis, in contrast to lung adenocarcinoma (30). These findings may be suggestive of differences in the underlying molecular mechanisms of tumorigenesis between carcinoids and LCNEC/SCLC and may also have therapeutic implications (28).

\section{Apoptosis}

Evasion of apoptosis is a well-known hallmark of cancer, with members of the BCL2 family actively implicated in this process both by promoting or hindering apoptosis, such as BCL2-associated X (BAX) and BCL2 respectively (31, 32). The expression of BCL2 and its activated form, namely phosphorylated BCL2 (pBCL2), was recently evaluated in surgical specimens of resectable, early-stage lung NET (33). The highest BCL2 expression was detected in LCNECs, while SCLCs had the highest pBCL2 expression. Carcinoids were at the bottom of the list regarding both molecules under investigation. Interestingly, higher pBCL2 levels were inversely associated with progression-free and overall survival (33). In another study of mRNA expression analysis, the $B C L 2 / B A X$ ratio increased throughout the spectrum of lung NETs, from typical and atypical carcinoids, LCNEC and SCLC (24). Furthermore, SCLC and lung cancer carcinomas with neuroendocrine differentiation did not express BCL2-associated athanogene 3 (BAG3), a BCL2-interacting protein that promotes antiapoptotic activity; however, the number of examined samples was rather limited (34).

These findings were indirectly confirmed by a study on human lung cancer cells, where the up-regulation of NOTCH1 was associated with decreased BCL2 expression which in turn, was presented as decreased apoptotic potential of cancer cells. This phenotype was significantly correlated with SCLC subtype (35).

CD44 is another molecule that promotes apoptosis and its role in lung NETs has been investigated. In fact, absence of CD44 expression has been correlated with significantly low 20-year survival in patients with pulmonary carcinoids (36). In parallel, Swarts et al. found that loss of expression of orthopedia homeobox (OTP) was an independent adverse prognostic factor of survival in patients with pulmonary carcinoids (36). Conversely, high CD44/OTP expression has been associated with improved recurrence-free and overall survival in patients with pulmonary carcinoids $(37,38)$. Thus, both CD44 and OTP have been suggested as novel candidates for the subclassification of pulmonary carcinoids in terms of prognosis $(36,38)$.

\section{NOTCH Family}

The NOTCH1 signaling pathway plays an important role in cell-cycle fate and is implicated in neuroendocrine differentiation of cells in the respiratory and gastrointestinal systems. NOTCH1 has a dual role in cancer, by acting either as a tumor-suppressor gene or as an oncogene, depending on tumor type $(39,40)$. It has been shown that NETs, including SCLC, are characterized by an increased expression of achaete-scute complex-like 1 (ASCL1) that promotes NET growth and is downregulated by NOTCH1 (39). Interestingly, a molecular pathway that promotes secondary SCLC has been identified and includes NOTCH inactivation with subsequent ASCL1 up-regulation and activation of the Wnt cascade that is amplified by concurrent RBI and TP53 mutations (41). Furthermore, the findings reported by Altree-Tacha et al. support the notion that ASCL1 has a high specificity for high-grade NETs compared to carcinoids (42). In SCLC, the up-regulation of the deactivated NOTCH1 pathway resulted in the suppression of cell growth and neuroendocirne differentiation, and induced an epithelial-like morphology of cell lines (35). However, NOTCH3, another member of the NOTCH pathway, did not have any effect on cell proliferation nor on neuroendocrine features of SCLC (43).

\section{Epithelial-Mesenchymal Transition}

Epithelial-mesenchymal transition (EMT) is considered to playa pivotal role in cancer propagation (44-48). This process, which normally occurs during embryonal development, consists of a cell shift from epithelial to mesenchymal phenotype $(44,45)$. In vitro induction of EMT in adult epithelial cells resulted in increased metastatic potential $(49,50)$. A cardinal step during EMT, the loss of cell-to-cell adherence, is mediated by the deregulation of cadherins $(48,51)$. In this context, two members of the 
Table I. Summary of biomarkers in lung neuroendocrine tumors.

\begin{tabular}{|c|c|}
\hline Biomarker category & Comments \\
\hline mTOR pathway & $\begin{array}{l}\text { - Higher expression in carcinoids }(10) \\
\text { - mTOR expression inversely associated with greater tumor stage in LCNEC and SCLC (10) } \\
\text { - Preclinical data: mTOR inhibitors reduce carcinoid proliferation, cell viability and VEGF secretion (12-14) } \\
\text { - RADIANT-4 phase III clinical trial: everolimus was associated with } 52 \% \text { reduction in the estimated risk } \\
\text { of progression or death }(p<0.00001)>>\text { FDA approval }(15-17) \\
\text { - Everolimus in combination with other agents in ongoing phase I and II clinical trials (16) } \\
\text { - Total mTOR levels, AKT, p70S6K (RPS6KB2), and ERK1/2 (MAPK3/1) protein levels predict sensitivity to } \\
\text { mTOR inhibitors in pulmonary carcinoids (18) } \\
\text { - Increased elF4E levels are associated with increased resistance to everolimus in SCLC (19) }\end{array}$ \\
\hline Cell cycle regulation genes & $\begin{array}{l}\text { - } R B 1 \text { and TP53: a significantly higher rate of mutations in carcinomas than in carcinoids }(p<0.0001)(20) \\
\text { - } R B 1 \text { and } T P 53 \text { transcription patterns may help distinguish between SCLC- and NSCLC-like LCNEC tumors }(20,21) \\
\text { - Lower expression of } A S C L 1, B C L 2, C A S P 8, C C N E 1, C D K 1, C D K 2, C D K N 1 A \text { and } C D K N 2 A \text { in } \\
\text { carcinoids compared to carcinomas }(22) \\
\text { - Higher expression of } C C N E 1 \text { and } C D K 6 \text { in carcinoids compared to carcinomas (22) } \\
\text { - Higher expression of } C D K 2, C D K N 1 B, C D K N 2 A \text { and } P N N \text { in SCLC compared to LCNEC }(22) \\
\text { - Minimal CCND1 and CDKN2A expression correlated with N0 status }(22) \\
\text { - ACTB, CDKN1B, GAPDH, GRB2, RHOA and SDCBP: reference genes in NETs (23) } \\
\text { - SCLC and LCNEC have similar DNTF expression associated with malignant neuroendocrine phenotype (25) } \\
\text { - LCNEC and SCLC: higher expression of nuclear surviving (28) }\end{array}$ \\
\hline Apoptosis & $\begin{array}{l}\text { - High pBCL2 expression: increased risk of disease progression and death (31) } \\
\text { - pBCL2: highest expression in SCLC, followed by LCNEC and lowest expression in carcinoid (31) } \\
\text { - BCL2/BAX ratio: increasing values from TC to AC, LCNEC and SCLC (22) } \\
\text { - Absence of CD44 expression: significantly low 20-year survival in patients with pulmonary } \\
\text { carcinoids adenocarcinomas (34) } \\
\text { - Loss of expression of OTP: independent adverse prognostic factor of survival in pulmonary carcinoids (34) } \\
\text { - High CD44/OTP expression: improved RFS and OS in pulmonary carcinoids }(35,36)\end{array}$ \\
\hline Notch family & $\begin{array}{l}\text { - Increased expression of ASCL1 promotes NET growth and is downregulated by NOTCH1 }(37,39) \\
\text { - ASCL1: high specificity for high-grade NETs compared to carcinoids }(40) \\
\text { - Up-regulation of the deactivated NOTCH1 pathway resulted in suppression of cell growth and } \\
\text { neuroendocirne differentiation (33) }\end{array}$ \\
\hline $\begin{array}{l}\text { Epithelial-mesenchymal } \\
\text { transition }\end{array}$ & $\begin{array}{l}\text { - E-Cadherin/ } \beta \text {-catenin complex loss of integrity: independently associated with LCNEC and SCLC subtypes, } \\
\text { lymph node infiltration and decreased RFS and OS (52) } \\
\text { - SNAI1 was the predictive marker with the highest significance to disease-related mortality (52) }\end{array}$ \\
\hline Ki-67 labeling index & $\begin{array}{l}\text { - Ki-67 labeling index is highly expressed in LCNEC and SCC compared to lung adenocarcinoma (28) } \\
\text { - Cutoff value for Ki-67 labeling index of 20\%, optimally discriminating between TC/AC and LCNEC/SCLC } \\
\text { with } 100 \% \text { sensitivity and specificity (56) }\end{array}$ \\
\hline $\begin{array}{l}\text { Chromatin-remodelling } \\
\text { genes }\end{array}$ & $\begin{array}{l}\text { - KMT2 family of covalent histone modifiers was mutated in } 13.6 \% \text { carcinoids versus } 26.7 \% \text { carcinomas } \\
(p=0.11) \text { and the ARID family, involved in the SWI-SNF complex had mutations in } 9.0 \% \text { carcinoids versus } \\
10.0 \% \text { carcinomas }(p<0.99)(20) \\
\text { - Most frequently encountered mutated genes were MEN1, PSIP1 and ARIDIA (26) }\end{array}$ \\
\hline MicroRNAs & $\begin{array}{l}\text { - } m i R-22, m i R-29 a, m i R-29 b, m i R-29 c, m i R-367^{*} ; m i R-504, m i R-513 C, m i R-1200 \text { : adverse association with } \\
\text { tumor grade }(59) \\
\text { - } m i R-18 a, m i R-15 b^{*}, m i R-335^{*}, m i R-1201 \text { : positive association with the tumor grade (59) } \\
\text { - let-7d, miR-19, miR-576-5p, miR-340*, and miR-1286: significantly associated with OS (59) }\end{array}$ \\
\hline Receptor Tyrosine Kinases & $\begin{array}{l}\text { - LCNEC and the SCLC tumors had significantly higher scores for c-KIT, IGF1R, and KDR and lower } \\
\text { scores for ERBB2, FGFR1, c-MET and ROS1, compared with adenocarcinomas (61) } \\
\text { - LCNEC and the SCLC tumors had significantly higher scores for c-KIT, KDR and RET and lower scores for EGFR } \\
\text { and IGF1R when compared with squamous cell carcinoma (61) } \\
\text { - RET mutations in SCLC are rare; M918T RET somatic mutation in metastatic SCLC tumor was related } \\
\text { with activation of ERK signaling, MYC expression and increased cell proliferation (63) } \\
\text { - Clinical data regarding patients with NET harbouring ALK rearrangements are derived from case reports (69) }\end{array}$ \\
\hline Heat shock protein & $\begin{array}{l}\text { - High expression of HSP90 in NETs (73) } \\
\text { - Small molecule HSP90 inhibitors reduced the viability of NCI-H727 human bronchopulmonary NET cell line (73) }\end{array}$ \\
\hline $\begin{array}{l}\text { Neuroendocrine (NE) tissue } \\
\text { markers }\end{array}$ & $\begin{array}{l}\text { - NE-negative patients: a significantly better prognosis than their NE-positive counterparts (74) } \\
\text { - Inverse association between CgA levels above } 100 \mathrm{pmol} / 1 \text { and OS (75) }\end{array}$ \\
\hline 4F2hc (CD98) & $\begin{array}{l}\text { - CD98 expression increased from low to high grade tumors and high 4F2he levels were associated with } \\
\text { poor OS }(77,78) \\
\text { - CD98 expression was associated with high GLUT1, HIF-1 } \alpha \text {, p-AKT, p-mTOR and p-S6K levels }(77,78)\end{array}$ \\
\hline
\end{tabular}


Table I. Continued

\begin{tabular}{ll}
\hline Biomarker category & Comments \\
\hline sREST & - High levels of sREST in SCLC cells (79) \\
& Preclinical studies with small-interfering RNAs (si-RNAs): encouraging results in suppressing sREST and \\
& restoring REST level (79) \\
YAP1 & High-grade NETs are specifically characterized by loss of YAP1 (80) \\
& YAP1-negative cases: more chemosensitive compared to YAP1-positive (80) \\
\hline
\end{tabular}

RFS: Recurrence-free survival; OS: overall survival; SCLC: small-cell lung carcinoma; LCNEC: large-cell neuroendocrine carcinoma; mTOR: mammalian target of rapamycin; IGF1R: insulin growth factor 1 receptor; KDR: kinase insert domain receptor; EGFR: epidermal growth factor receptor; ERBB2: erb-b2 receptor tyrosine kinase 2; FGFR1: fibroblast growth factor receptor 1; c-MET: MET proto-oncogene; ROS1: ROS protooncogene 1; RET: ret proto-oncogene; YAP1: Yes-associated protein 1; ASCL1: Achaete-scute homolog 1; BCL2: B-cell lymphoma 2; CASP8: caspase 8; CCNE1: $\mathrm{G}_{1} / \mathrm{S}$-specific cyclin-E1.

SNAIL protein family (namely SNAI1 and SNAI2), which suppress E-cadherin transcription, have been implicated in lung NETs $(52,53)$.

A recent study on surgically resected human lung tissue with NET demonstrated a low expression of E-cadherin and $\beta$-catenin in highly malignant tumors (54). Disintegration of E-cadherin $/ \beta$-catenin complex was independently associated with LCNEC and SCLC subtypes, lymph-node infiltration and decreased progression-free and overall survival (54). Furthermore, SNAI2 expression independently predicted lymph node involvement and reliably differentiated SCLC from LCNEC (54). SNAI1 was the predictive marker with the highest significance of association with disease-related mortality (7-fold risk for death due to the disease). Additionally, increased expression of E-cadherin and $\beta$ catenin was correlated with the histological subtype of typical carcinoid (54).

\section{Ki-67 Labeling Index}

$\mathrm{Ki}-67$ is a generally accepted proliferation marker (55) and the Ki-67 antigen-labeling index (LI), i.e. the percentage of labeled nuclei after immunohistochemical staining, is an emerging biomarker in NETs (56). The role of Ki-67 LI in lung NET has been the subject of several independent investigations, with potential diagnostic, prognostic, and grading implications (57). However, differences in Ki-67 LI are reported between the four histological variants (57). There is overlap between the histological categories, and Ki$67 \mathrm{LI}$ is not perfectly congruent with other defining criteria (57). Ki-67 is highly expressed in LCNEC and SCC compared to lung adenocarcinoma (30). Interestingly, a recent study on biopsy specimens suggested a cut-off value for $\mathrm{Ki}-67 \mathrm{LI}$ of $20 \%$ that optimally discriminates between typical/atypical carcinoid and LCNEC/SCLC with 100\% sensitivity and specificity (58).

\section{Chromatin-remodelling Genes}

Chromatin-remodeling genes have been suggested to play a key role in tumorigenesis; in fact, deregulation of these genes may be considered as a driver event of carcinogenesis in pulmonary carcinoids (28). Simbolo et al. showed that chromatin-remodeling genes were mutated in carcinoids $(45.5 \%)$ and carcinomas $(55.0 \%)$ at similar rates (22). Specifically, the histone-lysine $N$-methyltransferase 2 (KMT2) family of covalent histone modifiers (KMT2A, $K M T 2 C$ and KMT2D) was mutated in $13.6 \%$ carcinoids versus $26.7 \%$ carcinomas and the AT-rich interaction domain (ARID) family, involved in the switch/sucrose nonfermentable (SWI-SNF) complex (ARIDIA, ARIDIB, and ARID2), had mutations in $9.0 \%$ carcinoids versus $10.0 \%$ carcinomas (22). In another study, Fernandez-Cuesta et al. performed gene copy-number analysis, and genome/exome and transcriptome sequencing of pulmonary carcinoids, and covalent histone modifiers were found to be mutated in $40 \%$ of the cases, whereas mutated members of the SWI-SNF complex were detected in $22.2 \%$ of them. The most frequently encountered altered genes were MEN1, PSIP1 and SFRS1 interacting protein 1 (PSIP1), and ARIDIA (28).

$K M T 2 D$ exhibited truncating nonsense/frameshift/splice site mutations in $8 \%$ of SCLC tumors and $17 \%$ of SCLC cell lines in the study by Augert et al. These mutations in human SCLC cell lines were associated with reduced lysine methyltransferase 2D protein levels and reduced monomethylation of histone H3 lysine 4 that are associated with transcriptional enhancers (59).

\section{MicroRNAs}

MicroRNAs (miRNAs) are small, non-coding, singlestranded RNAs that regulate the cell cycle through epigenetic modifications, which are deregulated in lung cancer (60). 
Mairinger et al. conducted a miRNA profiling study in 12 pulmonary NETs and found 12 miRNAs with highly significantly different expression (61). Among them, eight (miR-22, miR-29a, miR-29b, miR-29c, miR-367*; miR-504, $m i R-513 C$ and $m i R-1200)$ had an adverse association and four ( $m i R-18 a, m i R-15 b^{*}, m i R-335^{*}$ and $\left.m i R-1201\right)$ had a positive association with tumor grade. This finding signifies a differential role for each miRNA in lung NET. Interestingly, five miRNAs (let-7d, miR-19, miR-576-5p, $m i R-340^{*}$, and $\left.m i R-1286\right)$ were significantly associated with increased overall survival, suggesting that they may have an important role in disease progression (61). Larger studies might be able to pinpoint differences in miRNA expression among subtypes of lung NETs.

\section{Receptor Tyrosine Kinases}

Receptor tyrosine kinases (RTKs) have a cardinal role in cancerassociated molecular signaling cascades, and they may be promising targets for drug development (62). Expression of RTKs [c-KIT, insulin growth factor 1 receptor (IGF1R), kinase insert domain receptor (KDR), epidermal growth factor receptor (EGFR), erb-b2 receptor tyrosine kinase 2 (ERBB2), fibroblast growth factor receptor 1 (FGFR1), MET proto-oncogene; c-MET, ROS proto-oncogene 1 (ROS1) and ret proto-oncogene (RET)] was evaluated by immunohistochemical staining in a comparative study that included lung NETs, adenocarcinomas and squamous cell carcinomas (63). Of interest, no difference was noted among lung NET subtypes (LCNEC and SCLC) but significant differences in immunohistochemical score were noted between NETs and the other lung carcinomas under investigation (63). Both LCNEC and SCLC had significantly higher immunohistochemical scores for c-KIT, IGF1R and KDR, and lower scores for ERBB2, FGFR1, c-MET and ROS1 compared with lung adenocarcinomas. In addition, LCNECs and SCLCs had significantly higher scores for c-KIT, KDR and RET and lower scores for EGFR and IGF1R when compared with squamous cell carcinoma (63).

The RET tyrosine kinase receptor plays a key role in neuroendocrine development and RET mutations have been long known in patients with multiple endocrine neoplasia type 2 (MEN2) syndromes (64). RET mutations have also been described in SCLC; in the setting of metastatic SCLC, Dabir et al. identified the M918T RET mutation, which was associated with activation of ERK signaling, MYC expression and increased cell proliferation (65). Furthermore, non-germline RET mutations in exon 11 were identified in two patients with SCLC (66). However, RET mutations in SCLC are considered relatively rare, taking into consideration the results of previous studies, which performed genomic analyses of SCLC cell lines and human tissue, and failed to provide sufficient evidence for the presence of RET mutations (67-69).
Regarding anaplastic lymphoma kinase ( $A L K$ ) gene rearrangement, Nakamura et al. did not find any $A L K$ rearrangement in 227 pulmonary NETs (70). In addition, clinical data regarding patients with NET harboring $A L K$ rearrangements were derived from case reports. The efficacy of ALK inhibitors, such as crizotinib, is rather questionable in these cases (71).

\section{Heat-shock Protein 90}

Heat-shock protein 90 (HSP90) constitutes a molecular chaperone regulating key oncoproteins that induce carcinogenesis (72). High expression of HSP90 has been found in NETs, whereas HSP90 inhibitors have shown efficacy in gastrointestinal and pancreatic NETs in the preclinical setting (73-75). AUY922 and HSP990 are novel small molecule HSP90 inhibitors that reduce the viability of NCI-H727 human bronchopulmonary NET cell line in a dose-dependent manner (75).

\section{Neuroendocrine Tissue Markers}

Synaptophysin , chromogranin A ( $\mathrm{CgA})$, neural cell adhesion molecule and CD56 are well-established neuroendocrine tissue markers (40). Hamanaka et al. evaluated tissue and serum neuroendocrine markers to differentiate SCLC from LCNEC in patients with both resectable and advanced disease (tissue retrieved by biopsy) (76). The striking finding of the study was that neuroendocrine-negative patients demonstrated a significantly better prognosis than their neuroendocrine-positive counterparts. This SCLC subset with good prognosis, identified by low neuroendocrine marker expression, was found only in resectable cases (76). Pericleous et al. confirmed these observations by demonstrating an inverse association between serum $\mathrm{CgA}$ levels above $100 \mathrm{pmol} / \mathrm{l}$ and overall survival (77). It should be noted that special attention is needed in the interpretation of the results, taking into consideration the fact that comorbidities of each patient may alter biomarker levels, such as in the case of $\mathrm{CgA}$ (78).

\section{Other Markers}

CD98 is a molecule involved in cell-cell signaling and its deregulation has been described in malignant tumors. In pulmonary NETs, expression of CD98 increased from lowto high-grade tumors and high levels were associated with poor overall survival. Furthermore, its expression was associated with high levels of glucose transporter 1 (GLUT1), hypoxia-inducible factor 1-alpha (HIF1 $\alpha$ ), p-AKT, p-mTOR and p-S6K protein that are known to be implicated in NET carcinogenesis and are highly expressed in NETs $(79,80)$. 
SCLC cells have been found to have high levels of soluble RE1-silencing transcription factor (sREST), which is an SCLC-specific isoform of RE1-silencing transcription factor that regulates expression of neuronal markers. This finding combined with the low level of REST expression suggest a mechanism of alternative splicing of REST in SCLC that is regulated by neural-specific Ser/Arg repeat-related protein of $100 \mathrm{kDa}$ (nSR100). This pathway is implicated in tumorextracellular matrix interactions that promote tumor proliferation. Preclinical studies with small-interfering RNAs have demonstrated encouraging results in suppressing sREST and restoring the REST level (81).

Yes-associated protein 1 (YAP1), the main Hippo pathway effector, is an oncogene implicated in the pathogenesis of lung cancer. Ito et al. showed high-grade NETs to be specifically characterized by loss of YAP1. Additionally, YAP1-negative cases were more chemosensitive compared to YAP1-positive ones. Thus, YAP1 is an emerging marker of neuroendocrine nature and a potential predictive factor of response to treatment of pulmonary NETs (82). Table I summarizes the biomarkers included in the present study.

\section{Conclusion}

Histological classification of lung NET is controversial due to lack of absolute concordance among the current classifications $(19,83)$. Interobserver variability can be overridden both by consensus meetings and by integrating molecular prognostic markers such as Ki67 and OTP; thus, a more accurate characterization and a better prediction of survival can be provided (84). The majority of studies evaluating the genomics of lung NETs were performed on paraffin-embedded human tissues from patients with resectable early-stage disease. Thus, these results cannot be generalized to all patients with lung NET because the majority of them have unresectable disease at diagnosis. Further translational research is considered indispensable in order to determine easily druggable molecular targets, such as gain of function mutations. These findings do offer important insight into the molecular pathways involved in each NET subtype and might facilitate design of novel therapeutic protocols.

Currently, clinical oncology is more personalized than ever before and different problems are treated differently. The development of multivariable predictive models evaluating baseline patient characteristics and molecular fingerprints of tumor biology are enhancing patient-specific therapeutic strategies. However, therapeutic approaches in patients with primary lung NETs need more randomization and comprehensive evidence-based data regarding the efficacy and the long-term outcomes of implicated treatments. In this context, ongoing (83) and future clinical trials integrating molecular profiling are deemed necessary in order to treat patients with lung NETs on a personalized basis.

\section{Funding}

This research did not receive any specific grant from funding agencies in the public, commercial, or not-for-profit sectors.

\section{References}

1 Travis WD, Brambilla E, Nicholson AG, Yatabe Y, Austin JH, Beasley MB, Chirieac LR, Dacic S, Duhig E, Flieder DB, Geisinger K, Hirsch FR, Ishikawa Y, Kerr KM, Noguchi M, Pelosi G, Powell CA, Tsao MS, Wistuba I and Panel WHO: The 2015 world health organization classification of lung tumors: Impact of genetic, clinical and radiologic advances since the 2004 classification. J Thorac Oncol 10(9): 1243-1260, 2015.

2 Global Burden of Disease Cancer C, Fitzmaurice C, Allen C, Barber RM, Barregard L, Bhutta ZA, Brenner H, Dicker DJ, Chimed-Orchir O, Dandona R, Dandona L, Fleming $\mathrm{T}$, Forouzanfar MH, Hancock J, Hay RJ, Hunter-Merrill R, Huynh C, Hosgood HD, Johnson CO, Jonas JB, Khubchandani J, Kumar GA, Kutz M, Lan Q, Larson HJ, Liang X, Lim SS, Lopez AD, MacIntyre MF, Marczak L, Marquez N, Mokdad AH, Pinho C, Pourmalek F, Salomon JA, Sanabria JR, Sandar L, Sartorius B, Schwartz SM, Shackelford KA, Shibuya K, Stanaway J, Steiner C, Sun J, Takahashi K, Vollset SE, Vos T, Wagner JA, Wang H, Westerman R, Zeeb H, Zoeckler L, AbdAllah F, Ahmed MB, Alabed S, Alam NK, Aldhahri SF, Alem G, Alemayohu MA, Ali R, Al-Raddadi R, Amare A, Amoako Y, Artaman A, Asayesh H, Atnafu N, Awasthi A, Saleem HB, Barac A, Bedi N, Bensenor I, Berhane A, Bernabe E, Betsu B, Binagwaho A, Boneya D, Campos-Nonato I, Castaneda-Orjuela C, Catala-Lopez F, Chiang P, Chibueze C, Chitheer A, Choi JY, Cowie B, Damtew S, das Neves J, Dey S, Dharmaratne S, Dhillon P, Ding E, Driscoll T, Ekwueme D, Endries AY, Farvid M, Farzadfar F, Fernandes J, Fischer F, TT GH, Gebru A, Gopalani S, Hailu A, Horino M, Horita N, Husseini A, Huybrechts I, Inoue M, Islami F, Jakovljevic M, James S, Javanbakht M, Jee SH, Kasaeian A, Kedir MS, Khader YS, Khang YH, Kim D, Leigh J, Linn S, Lunevicius R, El Razek HM, Malekzadeh R, Malta DC, Marcenes W, Markos D, Melaku YA, Meles KG, Mendoza W, Mengiste DT, Meretoja TJ, Miller TR, Mohammad KA, Mohammadi A, Mohammed S, MoradiLakeh M, Nagel G, Nand D, Le Nguyen Q, Nolte S, Ogbo FA, Oladimeji KE, Oren E, Pa M, Park EK, Pereira DM, Plass D, Qorbani M, Radfar A, Rafay A, Rahman M, Rana SM, Soreide K, Satpathy M, Sawhney M, Sepanlou SG, Shaikh MA, She J, Shiue I, Shore HR, Shrime MG, So S, Soneji S, Stathopoulou V, Stroumpoulis K, Sufiyan MB, Sykes BL, Tabares-Seisdedos R, Tadese F, Tedla BA, Tessema GA, Thakur JS, Tran BX, Ukwaja KN, Uzochukwu BS, Vlassov VV, Weiderpass E, Wubshet Terefe M, Yebyo HG, Yimam HH, Yonemoto N, Younis MZ, Yu C, Zaidi Z, Zaki ME, Zenebe ZM, Murray CJ and Naghavi M: Global, regional, and national cancer incidence, mortality, years of life lost, years lived with disability, and disability-adjusted life-years for 32 cancer groups, 1990 to 2015: A systematic analysis for the global burden of disease study. JAMA Oncol 3(4): 524-548, 2017.

3 Wolin EM: Challenges in the diagnosis and management of well-differentiated neuroendocrine tumors of the lung (typical and atypical carcinoid): Current status and future considerations. Oncologist 20(10): 1123-1131, 2015. 
4 Moris D and Pawlik TM: Personalized treatment in patients with colorectal liver metastases. J Surg Res 216: 26-29, 2017.

5 Moris D and Kontos M: Era of individualization of the surgical treatment of breast cancer: Similar problems can sometimes be treated differently. J Am Coll Surg 224(5): 995-996, 2017.

6 Biankin AV and Hudson TJ: Somatic variation and cancer: Therapies lost in the mix. Hum Genet 130(1): 79-91, 2011.

7 Righi L, Volante M, Rapa I, Vatrano S, Pelosi G and Papotti M: Therapeutic biomarkers in lung neuroendocrine neoplasia. Endocr Pathol 25(4): 371-377, 2014.

8 Moschetta M, Reale A, Marasco C, Vacca A and Carratu MR: Therapeutic targeting of the mtor-signalling pathway in cancer: Benefits and limitations. Br J Pharmacol 171(16): 3801-3813, 2014.

9 Grozinsky-Glasberg S and Pavel M: Inhibition of mTOR in carcinoid tumors. Target Oncol 7(3): 189-195, 2012.

10 Strosberg J: Evolving treatment strategies for management of carcinoid tumors. Curr Treat Options Oncol 14(3): 374-388, 2013.

11 Voortman J, Lee JH, Killian JK, Suuriniemi M, Wang Y, Lucchi M, Smith WI, Jr., Meltzer P, Wang Y and Giaccone G: Array comparative genomic hybridization-based characterization of genetic alterations in pulmonary neuroendocrine tumors. Proc Natl Acad Sci USA 107(29): 13040-13045, 2010.

12 Ali G, Boldrini L, Capodanno A, Pelliccioni S, Servadio A, Crisman G, Picchi A, Davini F, Mussi A and Fontanini G: Expression of p-Akt and p-mTOR in a large series of bronchopulmonary neuroendocrine tumors. Exp Ther Med 2(5): 787-792, 2011.

13 Miyoshi T, Umemura S, Matsumura Y, Mimaki S, Tada S, Makinoshima H, Ishii G, Udagawa H, Matsumoto S, Yoh K, Niho S, Ohmatsu H, Aokage K, Hishida T, Yoshida J, Nagai K, Goto K, Tsuboi $\mathrm{M}$ and Tsuchihara K: Genomic profiling of large-cell neuroendocrine carcinoma of the lung. Clin Cancer Res 23(3): 757-765, 2017.

14 Motylewska E, Lawnicka H, Kowalewicz-Kulbat M, Sicinska P, Niedziela A, Melen-Mucha G and Stepien H: Interferon alpha and rapamycin inhibit the growth of carcinoid and medullary thyroid cancer in vitro. Pharmacol Rep 66(4): 624-629, 2014.

15 Moreno A, Akcakanat A, Munsell MF, Soni A, Yao JC and Meric-Bernstam F: Antitumor activity of rapamycin and octreotide as single agents or in combination in neuroendocrine tumors. Endocr Relat Cancer 15(1): 257-266, 2008.

16 Zatelli MC, Minoia M, Martini C, Tagliati F, Ambrosio MR, Schiavon M, Buratto M, Calabrese F, Gentilin E, Cavallesco G, Berdondini L, Rea F and degli Uberti EC: Everolimus as a new potential antiproliferative agent in aggressive human bronchial carcinoids. Endocr Relat Cancer 17(3): 719-729, 2010.

17 Yao JC, Fazio N, Singh S, Buzzoni R, Carnaghi C, Wolin E, Tomasek J, Raderer M, Lahner H, Voi M, Pacaud LB, Rouyrre N, Sachs C, Valle JW, Delle Fave G, Van Cutsem E, Tesselaar M, Shimada Y, Oh DY, Strosberg J, Kulke MH, Pavel ME and Rad001 in Advanced Neuroendocrine Tumours FTSG: Everolimus for the treatment of advanced, non-functional neuroendocrine tumours of the lung or gastrointestinal tract (radiant-4): A randomised, placebo-controlled, phase 3 study. Lancet 387(10022): 968-977, 2016.

18 Phan AT and Dave B: The pivotal role of mammalian target of rapamycin inhibition in the treatment of patients with neuroendocrine tumors. Cancer Med 5(10): 2953-2964, 2016.
19 Wolin EM: Advances in the diagnosis and management of welldifferentiated and intermediate-differentiated neuroendocrine tumors of the lung. Chest 151(5): 1141-1146, 2017.

20 Gagliano T, Bellio M, Gentilin E, Mole D, Tagliati F, Schiavon M, Cavallesco NG, Andriolo LG, Ambrosio MR, Rea F, Degli Uberti E and Zatelli MC: Mtor, p70S6K, AKT, and ERK1/2 levels predict sensitivity to mTOR and $\mathrm{PI} 3 \mathrm{~K} / \mathrm{mTOR}$ inhibitors in human bronchial carcinoids. Endocr Relat Cancer 20(4): 463-475, 2013.

21 Matsumoto M, Seike M, Noro R, Soeno C, Sugano T, Takeuchi S, Miyanaga A, Kitamura K, Kubota K and Gemma A: Control of the MYC-EIF4E axis plus mTOR inhibitor treatment in small cell lung cancer. BMC Cancer 15: 241, 2015.

22 Simbolo M, Mafficini A, Sikora KO, Fassan M, Barbi S, Corbo V, Mastracci L, Rusev B, Grillo F, Vicentini C, Ferrara R, Pilotto S, Davini F, Pelosi G, Lawlor RT, Chilosi M, Tortora G, Bria E, Fontanini G, Volante $\mathrm{M}$ and Scarpa A: Lung neuroendocrine tumours: Deep sequencing of the four world health organization histotypes reveals chromatin-remodelling genes as major players and a prognostic role for TERT, RB1, MEN1 and KMT2D. J Pathol 241(4): 488-500, 2017.

23 Karlsson A, Brunnstrom H, Micke P, Veerla S, Mattsson J, La Fleur L, Botling J, Jonsson M, Reutersward C, Planck M and Staaf J: Gene expression profiling of large cell lung cancer links transcriptional phenotypes to the new histological WHO 2015 classification. J Thorac Oncol 12(8): 1257-1267, 2017.

24 Walter RF, Werner R, Ting S, Vollbrecht C, Theegarten D, Christoph DC, Schmid KW, Wohlschlaeger J and Mairinger FD: Identification of deregulation of apoptosis and cell cycle in neuroendocrine tumors of the lung via nanostring ncounter expression analysis. Oncotarget 6(28): 24690-24698, 2015.

25 Walter RF, Werner R, Vollbrecht C, Hager T, Flom E, Christoph DC, Schmeller J, Schmid KW, Wohlschlaeger J and Mairinger FD: $A C T B, C D K N 1 B, G A P D H, G R B 2, R H O A$ and $S D C B P$ were identified as reference genes in neuroendocrine lung cancer via the nCounter technology. PLoS One 11(11): e0165181, 2016.

26 D'Adda T, Pelosi G, Lagrasta C, Azzoni C, Bottarelli L, Pizzi S, Troisi I, Rindi G and Bordi C: Genetic alterations in combined neuroendocrine neoplasms of the lung. Mod Pathol 21(4): 414422, 2008.

27 Endo T, Yazawa T, Shishido-Hara Y, Fujiwara M, Shimoyamada H, Ishii J, Sato H, Tachibana K, Takei H, Kondo H, Goya T, Endo $\mathrm{S}$ and Kamma $\mathrm{H}$ : Expression of developing neural transcription factors in lung carcinoid tumors. Pathol Int 64(8): 365-374, 2014.

28 Fernandez-Cuesta L, Peifer M, Lu X, Sun R, Ozretic L, Seidel D, Zander T, Leenders F, George J, Muller C, Dahmen I, Pinther B, Bosco G, Konrad K, Altmuller J, Nurnberg P, Achter V, Lang U, Schneider PM, Bogus M, Soltermann A, Brustugun OT, Helland A, Solberg S, Lund-Iversen M, Ansen S, Stoelben E, Wright GM, Russell P, Wainer Z, Solomon B, Field JK, Hyde R, Davies MP, Heukamp LC, Petersen I, Perner S, Lovly CM, Cappuzzo F, Travis WD, Wolf J, Vingron M, Brambilla E, Haas $\mathrm{SA}$, Buettner $\mathrm{R}$ and Thomas RK: Frequent mutations in chromatin-remodelling genes in pulmonary carcinoids. Nat Commun 5: 3518, 2014.

29 Escudero AG, Zarco ER, Arjona JC, Moreno MJ, Rodriguez KG, Benitez AV and Campora RG: Expression of developing neural transcription factors in diffuse idiopathic pulmonary neuroendocrine cell hyperplasia (DIPNECH). Virchows Arch 469(3): 357-363, 2016. 
30 Hirano H, Maeda H, Yamaguchi T, Yokota S, Mori M and Sakoda S: Survivin expression in lung cancer: Association with smoking, histological types and pathological stages. Oncol Lett 10(3): 1456-1462, 2015.

31 Naranjo Gomez JM, Bernal JF, Arranz PG, Fernandez SL and Roman JJ: Alterations in the expression of p53, KLF4, and p21 in neuroendocrine lung tumors. Arch Pathol Lab Med 138(7): 936-942, 2014.

32 Hanahan D and Weinberg RA: The hallmarks of cancer. Cell 100(1): 57-70, 2000.

33 Chowdry RP, Sica GL, Kim S, Chen Z, Goodman A, Alexis D, Deng $X$ and Owonikoko TK: Phosphorylated BCL-2 and MCL1 as prognostic markers in small cell lung cancer. Oncotarget, 2016. https://doi.org/10.18632/oncotarget.7485

34 Yeo CD, Park GS, Kang N, Choi SY, Kim HY, Lee DS, Kim YS, Kim YK, Park JG, Sung SW, Lee KY, Park MS, Yim HW, Kim SJ and Lee JH: BIS expression in patients with surgically resected lung cancer and its clinical significance. Ann Surg Oncol 22(Suppl 3): S1365-1370, 2015.

35 Wael H, Yoshida R, Kudoh S, Hasegawa K, Niimori-Kita K and Ito T: Notch1 signaling controls cell proliferation, apoptosis and differentiation in lung carcinoma. Lung Cancer 85(2): 131-140, 2014.

36 Swarts DR, Henfling ME, Van Neste L, van Suylen RJ, Dingemans AM, Dinjens WN, Haesevoets A, Rudelius M, Thunnissen E, Volante M, Van Criekinge W, van Engeland M, Ramaekers FC and Speel EJ: CD44 and OTP are strong prognostic markers for pulmonary carcinoids. Clin Cancer Res 19(8): 2197-2207, 2013.

37 Granberg D, Wilander E, Oberg K and Skogseid B: Decreased survival in patients with CD44-negative typical bronchial carcinoid tumors. Int J Cancer 84(5): 484-488, 1999.

38 Papaxoinis G, Nonaka D, O'Brien C, Sanderson B, Krysiak P and Mansoor W: Prognostic significance of CD44 and orthopedia homeobox protein (OTP) expression in pulmonary carcinoid tumours. Endocr Pathol 28(1): 60-70, 2017.

39 Kunnimalaiyaan $\mathrm{M}$ and Chen $\mathrm{H}$ : Tumor suppressor role of NOTCH-1 signaling in neuroendocrine tumors. Oncologist 12(5): 535-542, 2007.

40 Crabtree JS, Singleton CS and Miele L: Notch signaling in neuroendocrine tumors. Front Oncol 6: 94, 2016.

41 Meder L, Konig K, Ozretic L, Schultheis AM, Ueckeroth F, Ade CP, Albus K, Boehm D, Rommerscheidt-Fuss U, Florin A, Buhl T, Hartmann W, Wolf J, Merkelbach-Bruse S, Eilers M, Perner S, Heukamp LC and Buettner R: NOTCH, ASCL1, P53 and RB alterations define an alternative pathway driving neuroendocrine and small cell lung carcinomas. Int J Cancer 138(4): 927-938, 2016.

42 Altree-Tacha D, Tyrrell J and Li F: MASH1 is highly specific for neuroendocrine carcinomas: An immunohistochemical evaluation on normal and various neoplastic tissues. Arch Pathol Lab Med 141(2): 288-292, 2017.

43 Hassan WA, Yoshida R, Kudoh S, Motooka Y and Ito T: Evaluation of role of NOTCH3 signaling pathway in human lung cancer cells. J Cancer Res Clin Oncol 142(5): 981-993, 2016.

44 Thiery JP and Sleeman JP: Complex networks orchestrate epithelial-mesenchymal transitions. Nat Rev Mol Cell Biol 7(2): 131-142, 2006.

45 Shook D and Keller R: Mechanisms, mechanics and function of epithelial-mesenchymal transitions in early development. Mech Dev 120(11): 1351-1383, 2003.
46 Lee JM, Dedhar S, Kalluri R and Thompson EW: The epithelialmesenchymal transition: New insights in signaling, development, and disease. J Cell Biol 172(7): 973-981, 2006.

47 Natalwala A, Spychal $R$ and Tselepis C: Epithelialmesenchymal transition mediated tumourigenesis in the gastrointestinal tract. World J Gastroenterol 14(24): 3792-3797, 2008.

48 Schizas D, Moris D, Kanavidis P, Michalinos A, Sioulas A, Pavlakis K, Machairas A and Liakakos T: The prognostic value of CD44 expression in epithelial-mesenchymal transition: Preliminary data from patients with gastric and esophageal cancer. In Vivo 30(6): 939-944, 2016.

49 Huber MA, Kraut N and Beug H: Molecular requirements for epithelial-mesenchymal transition during tumor progression. Curr Opin Cell Biol 17(5): 548-558, 2005.

50 Thiery JP: Epithelial-mesenchymal transitions in tumour progression. Nat Rev Cancer 2(6): 442-454, 2002.

51 Hugo H, Ackland ML, Blick T, Lawrence MG, Clements JA, Williams ED and Thompson EW: Epithelial--mesenchymal and mesenchymal - epithelial transitions in carcinoma progression. J Cell Physiol 213(2): 374-383, 2007.

52 Batlle E, Sancho E, Franci C, Dominguez D, Monfar M, Baulida $\mathrm{J}$ and Garcia De Herreros A: The transcription factor snail is a repressor of E-cadherin gene expression in epithelial tumour cells. Nat Cell Biol 2(2): 84-89, 2000.

53 Bolos V, Peinado H, Perez-Moreno MA, Fraga MF, Esteller M and Cano A: The transcription factor slug represses E-cadherin expression and induces epithelial to mesenchymal transitions: A comparison with SNAIL and E47 repressors. J Cell Sci 116(Pt 3): 499-511, 2003.

54 Galvan JA, Astudillo A, Vallina A, Crespo G, Folgueras MV and Gonzalez MV: Prognostic and diagnostic value of epithelial to mesenchymal transition markers in pulmonary neuroendocrine tumors. BMC Cancer 14: 855, 2014.

55 Pelosi G and Zamboni G: Proliferation markers and their uses in the study of endocrine tumors. Endocr Pathol 7(2): 103-119, 1996.

56 Rindi G, Kloppel G, Couvelard A, Komminoth P, Korner M, Lopes JM, McNicol AM, Nilsson O, Perren A, Scarpa A, Scoazec JY and Wiedenmann B: Tnm staging of midgut and hindgut (neuro) endocrine tumors: A consensus proposal including a grading system. Virchows Arch 451(4): 757-762, 2007.

57 Pelosi G, Fabbri A, Cossa M, Sonzogni A, Valeri B, Righi L and Papotti M: What clinicians are asking pathologists when dealing with lung neuroendocrine neoplasms? Semin Diagn Pathol 32(6): 469-479, 2015.

58 Fabbri A, Cossa M, Sonzogni A, Papotti M, Righi L, Gatti G, Maisonneuve P, Valeri B, Pastorino U and Pelosi G: Ki-67 labeling index of neuroendocrine tumors of the lung has a high level of correspondence between biopsy samples and surgical specimens when strict counting guidelines are applied. Virchows Arch 470(2): 153-164, 2017.

59 Augert A, Zhang Q, Bates B, Cui M, Wang X, Wildey G, Dowlati A and MacPherson D: Small cell lung cancer exhibits frequent inactivating mutations in the histone methyltransferase KMT2D/MLL2: CALGB 151111 (alliance). J Thorac Oncol 12(4): 704-713, 2016.

60 Del Vescovo V and Denti MA: Microrna and lung cancer. Adv Exp Med Biol 889: 153-177, 2015. 
61 Mairinger FD, Ting S, Werner R, Walter RF, Hager T, Vollbrecht C, Christoph D, Worm K, Mairinger T, Sheu-Grabellus SY, Theegarten D, Schmid KW and Wohlschlaeger J: Different micro-rna expression profiles distinguish subtypes of neuroendocrine tumors of the lung: Results of a profiling study. Mod Pathol 27(12): 1632-1640, 2014.

62 Umemura S, Mimaki S, Makinoshima H, Tada S, Ishii G, Ohmatsu H, Niho S, Yoh K, Matsumoto S, Takahashi A, Morise M, Nakamura Y, Ochiai A, Nagai K, Iwakawa R, Kohno T, Yokota J, Ohe Y, Esumi H, Tsuchihara $\mathrm{K}$ and Goto $\mathrm{K}$ : Therapeutic priority of the PI3K/AKT/mTOR pathway in small cell lung cancers as revealed by a comprehensive genomic analysis. J Thorac Oncol 9(9): 1324-1331, 2014.

63 Matsumura Y, Umemura S, Ishii G, Tsuta K, Matsumoto S, Aokage K, Hishida T, Yoshida J, Ohe Y, Suzuki H, Ochiai A, Goto K, Nagai $\mathrm{K}$ and Tsuchihara K: Expression profiling of receptor tyrosine kinases in high-grade neuroendocrine carcinoma of the lung: A comparative analysis with adenocarcinoma and squamous cell carcinoma. J Cancer Res Clin Oncol 141(12): 2159-2170, 2015.

64 Eng C, Clayton D, Schuffenecker I, Lenoir G, Cote G, Gagel RF, van Amstel HK, Lips CJ, Nishisho I, Takai SI, Marsh DJ, Robinson BG, Frank-Raue K, Raue F, Xue F, Noll WW, Romei C, Pacini F, Fink M, Niederle B, Zedenius J, Nordenskjold M, Komminoth P, Hendy GN and Mulligan LM: The relationship between specific RET proto-oncogene mutations and disease phenotype in multiple endocrine neoplasia type 2. International RET Mutation Consortium Analysis. JAMA 276(19): 1575-1579, 1996.

65 Dabir S, Babakoohi S, Kluge A, Morrow JJ, Kresak A, Yang M, MacPherson D, Wildey $\mathrm{G}$ and Dowlati A: RET mutation and expression in small-cell lung cancer. J Thorac Oncol 9(9): 13161323, 2014.

66 Futami H, Egawa S, Tsukada T, Maruyama K, Bandoh S, Noguchi $\mathrm{M}$ and Yamaguchi K: A novel somatic point mutation of the RET proto-oncogene in tumor tissues of small cell lung cancer patients. Jpn J Cancer Res 86(12): 1127-1130, 1995.

67 Mulligan LM, Timmer T, Ivanchuk SM, Campling BG, Young LC, Rabbitts PH, Sundaresan V, Hofstra RM and Eng C: Investigation of the genes for RET and its ligand complex, GDNF/GFR $\alpha-I$, in small cell lung carcinoma. Genes Chromosomes Cancer 21(4): 326-332, 1998.

68 Rudin CM, Durinck S, Stawiski EW, Poirier JT, Modrusan Z, Shames DS, Bergbower EA, Guan Y, Shin J, Guillory J, Rivers CS, Foo CK, Bhatt D, Stinson J, Gnad F, Haverty PM, Gentleman R, Chaudhuri S, Janakiraman V, Jaiswal BS, Parikh C, Yuan W, Zhang Z, Koeppen H, Wu TD, Stern HM, Yauch RL, Huffman KE, Paskulin DD, Illei PB, Varella-Garcia M, Gazdar AF, de Sauvage FJ, Bourgon R, Minna JD, Brock MV and Seshagiri S: Comprehensive genomic analysis identifies SOX2 as a frequently amplified gene in small-cell lung cancer. Nat Genet 44(10): 1111-1116, 2012.

69 Peifer M, Fernandez-Cuesta L, Sos ML, George J, Seidel D, Kasper LH, Plenker D, Leenders F, Sun R, Zander T, Menon R, Koker M, Dahmen I, Muller C, Di Cerbo V, Schildhaus HU, Altmuller J, Baessmann I, Becker C, de Wilde B, Vandesompele J, Bohm D, Ansen S, Gabler F, Wilkening I, Heynck S, Heuckmann JM, Lu X, Carter SL, Cibulskis K, Banerji S, Getz G, Park KS, Rauh D, Grutter C, Fischer M, Pasqualucci L, Wright G, Wainer Z, Russell P, Petersen I, Chen Y, Stoelben E,
Ludwig C, Schnabel P, Hoffmann H, Muley T, Brockmann M, Engel-Riedel W, Muscarella LA, Fazio VM, Groen H, Timens W, Sietsma H, Thunnissen E, Smit E, Heideman DA, Snijders PJ, Cappuzzo F, Ligorio C, Damiani S, Field J, Solberg S, Brustugun OT, Lund-Iversen M, Sanger J, Clement JH, Soltermann A, Moch H, Weder W, Solomon B, Soria JC, Validire P, Besse B, Brambilla E, Brambilla C, Lantuejoul S, Lorimier P, Schneider PM, Hallek M, Pao W, Meyerson M, Sage J, Shendure J, Schneider R, Buttner R, Wolf J, Nurnberg P, Perner S, Heukamp LC, Brindle PK, Haas $S$ and Thomas RK: Integrative genome analyses identify key somatic driver mutations of small-cell lung cancer. Nat Genet 44(10): 1104-1110, 2012.

70 Nakamura H, Tsuta K, Yoshida A, Shibata T, Wakai S, Asamura $\mathrm{H}$, Furuta $\mathrm{K}$ and Tsuda $\mathrm{H}$ : Aberrant anaplastic lymphoma kinase expression in high-grade pulmonary neuroendocrine carcinoma. J Clin Pathol 66(8): 705-707, 2013.

71 Nakajima M, Uchiyama N, Shigemasa R, Matsumura T, Matsuoka R and Nomura A: Atypical carcinoid tumor with anaplastic lymphoma kinase $(A L K)$ rearrangement successfully treated by an alk inhibitor. Intern Med 55(21): 3151-3153, 2016.

72 Trepel J, Mollapour M, Giaccone G and Neckers L: Targeting the dynamic HSP90 complex in cancer. Nat Rev Cancer 10(8): 537-549, 2010.

73 Gilbert JA, Adhikari LJ, Lloyd RV, Rubin J, Haluska P, Carboni JM, Gottardis MM and Ames MM: Molecular markers for novel therapies in neuroendocrine (carcinoid) tumors. Endocr Relat Cancer 17(3): 623-636, 2010.

74 Gloesenkamp C, Nitzsche B, Lim AR, Normant E, Vosburgh E, Schrader M, Ocker M, Scherubl H and Hopfner M: Heat-shock protein 90 is a promising target for effective growth inhibition of gastrointestinal neuroendocrine tumors. Int J Oncol 40(5): 1659-1667, 2012.

75 Zitzmann K, Ailer G, Vlotides G, Spoettl G, Maurer J, Goke B, Beuschlein F and Auernhammer CJ: Potent antitumor activity of the novel HSP90 inhibitors AUY922 and HSP990 in neuroendocrine carcinoid cells. Int J Oncol 43(6): 1824-1832, 2013.

76 Hamanaka W, Motoi N, Ishikawa S, Ushijima M, Inamura K, Hatano S, Uehara H, Okumura S, Nakagawa K, Nishio M, Horai T, Aburatani H, Matsuura M, Iwasaki A and Ishikawa Y: A subset of small cell lung cancer with low neuroendocrine expression and good prognosis: A comparison study of surgical and inoperable cases with biopsy. Hum Pathol 45(5): 1045-1056, 2014.

77 Pericleous M, Karpathakis A, Toumpanakis C, Lumgair H, Reiner J, Marelli L, Thirlwell C and Caplin ME: Welldifferentiated bronchial neuroendocrine tumors: Clinical management and outcomes in 105 patients. Clin Respir J, 2016. doi: 10.1111/crj.12603. [Epub ahead of print]

78 Gerber DE, Paik PK and Dowlati A: Beyond adenocarcinoma: Current treatments and future directions for squamous, small cell, and rare lung cancer histologies. Am Soc Clin Oncol Educ Book 2015: 147-162, 2015.

79 Kaira K, Ohde Y, Endo M, Nakagawa K, Okumura T, Takahashi T, Murakami H, Tsuya A, Nakamura Y, Naito T, Kondo H, Nakajima T and Yamamoto N: Expression of 4F2HC (CD98) in pulmonary neuroendocrine tumors. Oncol Rep 26(4): 931-937, 2011.

80 Benzerdjeb N, Berna P and Sevestre H: Glut1: A novel tool reflecting proliferative activity of lung neuroendocrine tumors? Pathol Int 67(1): 32-36, 2017. 
81 Shimojo M, Shudo Y, Ikeda M, Kobashi T and Ito S: The small cell lung cancer-specific isoform of re1-silencing transcription factor (REST) is regulated by neural-specific Ser/Arg repeatrelated protein of $100 \mathrm{kDA}$ (NSR100). Mol Cancer Res 11(10): 1258-1268, 2013.

82 Ito T, Matsubara D, Tanaka I, Makiya K, Tanei ZI, Kumagai Y, Shiu SJ, Nakaoka HJ, Ishikawa S, Isagawa T, Morikawa T, Shinozaki-Ushiku A, Goto Y, Nakano T, Tsuchiya T, Tsubochi H, Komura D, Aburatani H, Dobashi Y, Nakajima J, Endo S, Fukayama M, Sekido Y, Niki T and Murakami Y: Loss of YAP1 defines neuroendocrine differentiation of lung tumors. Cancer Sci 107(10): 1527-1538, 2016.

83 Hendifar AE, Marchevsky AM and Tuli R: Neuroendocrine tumors of the lung: Current challenges and advances in the diagnosis and management of well-differentiated disease. $\mathbf{J}$ Thorac Oncol 12(3): 425-436, 2017.

84 Swarts DR, van Suylen RJ, den Bakker MA, van Oosterhout MF, Thunnissen FB, Volante M, Dingemans AM, Scheltinga MR, Bootsma GP, Pouwels HM, van den Borne BE, Ramaekers FC and Speel EJ: Interobserver variability for the WHO classification of pulmonary carcinoids. Am J Surg Pathol 38(10): 1429-1436, 2014.

Received October 15, 2017

Revised December 1, 2017

Accepted December 5, 2017 